\title{
Sandwich-Type Complexes of Erbium(III) and Gadolinium(III) with $R$-Phenoxy-Substituted Phthalocyanines
}

\author{
Tatyana V. Tikhomirova, ${ }^{@}$ Anna A. Filippova, Darya K. Govorova, \\ Gennady P. Shaposhnikov, and Artur S. Vashurin
}

Dedicated to Professor Oleg A. Golubchikov on the occasion of his 70th Anniversary

Ivanovo State University of Chemistry and Technology, 153000 Ivanovo, Russia

${ }^{\circledR}$ Corresponding authorE-mail: tararjkina@mail.ru

Novel 4-\{[(1,1'-biphenyl)-4-yl]oxy\}- and 4-[(4-benzyloxy)phenoxy]phthalonitriles were synthesized. Corresponding metal-free phthalocyanines and double-decker complexes of erbium(III) and gadolinium(III) were obtained using the nitriles. Spectral properties of the synthesized compounds were studied.

Keywords: Phthalonitrile, double-decker phthalocyanine, lanthanide, synthesis, spectroscopy.

\section{Комплексы эрбия(III) и гадолиния(III) сэндвичевого типа с $\boldsymbol{R}$-феноксизамещенными фталоцианинами}

\author{
Т. В. Тихомирова, ${ }^{\circledR}$ А. А. Филиппова, А. К. Говорова, Г. П. Шапошников, \\ А. С. Вашурин
}

Посвящается Олегу Александровичу Голубчикову по случаю его 70-летнего юбилея

Ивановский государственный химико-технологический университет, 153000 Иваново, Россия

@E-mail: tararjkina@mail.ru

\begin{abstract}
Синтезировань 4-\{[(1,1'-бифенил)-4-ил]окси\}- и 4-[(4-бензилокси)фенокси]фталонитриль,, на основе которых получены соответствующие безметальные фталочиианиы, а также металлированием последних хлоридами эрбия и гадолиния получены соответствующие сэндвичевые двухпалубные комплексы. Исследованы спектральные свойства синтезированных соединений. Показано влияние металла-комплексообразователя на положение всех полос поглощения в ЭСП в органических растворителях.
\end{abstract}

Ключевые слова: Фталонитрил, дифталоцианин, лантанид, синтез, спектроскопия.

\section{Introduction}

Rare-earth elements being of big coordination number are able to form complexes of various structure with phthalocyanines, namely planar and sandwich-type ones. ${ }^{[1-3]}$ Suchlike compounds are prospective as organic semiconductors $^{[4-5]}$ and luminescent materials. ${ }^{[6-7]}$ Additionally, the complexes of lanthanides are capable of $4 f$-luminescence within near-IR region ${ }^{[1,8-10]}$ and materials made of them are used for light-emission devices production ${ }^{[6]}$ and medical diagnostics.
Sandwich complexes of double-decker structure are of certain interest. Such structural factors as nature of central metal cation and substituents of phthalocyanine macrocycle are known to determine its properties..$^{[1,2,11,12]}$ Mentioned factors are able to affect the interaction between $\pi$-systems of two macroligands significantly. Besides, the size of central metal's ionic radius influences the yield of the desired compound upon synthesis..$^{[2,3,11]}$ Regarding this statements two metals (erbium and gadolinium) of different radius were used in the work. 
Literature reports the data on synthesis of sandwich double-decker complexes of lanthanides, properties of which are studied. ${ }^{[1-3,11-14]}$ These works are generally devoted to phthalocyanines containing annulated crown ethers,,${ }^{[1,12-14]}$ alkyl of phenyl substituents on the periphery. ${ }^{[2,3,11]}$ There are almost no works devoted to synthesis of diphthalocyanines containing bulky aryloxy-groups being part of phthalocyanine chromophores.

Tetrasubstituted phthalocyanines having four bulky substituents without extended alkyl chains are able to form liquid-crystalline state of flying seeds-like structure existing within wide temperature range. Herewith, we observed only one report on such compounds having (1,1-diphenylethyl) phenoxy-, (1-methyl-1-phenylethyl)phenoxy and (tert-butyl) phenoxy substituents with copper atom being in coordination space. ${ }^{[15]}$ The literature also reports zinc complex of tetra4-[4-(4-benzyloxy)phenoxy]phthalocyanine to exhibit fluorescent properties. ${ }^{[16]}$ However, there is no information on metal complexes with lanthanides of such structure reported.

In this way, finding out the possibility of obtainment of lanthanide complexes having similar structure by developing the synthesis is of great importance. Main problem of this task is formation of products mixture being hardly separated.

Summarizing all above, one can conclude the works devoted to synthesis and extraction of lanthanide complexes containing bulky functional substituents on the periphery of phthalocyanine ligand, properties of which are studied, to be topical.

Present work provides data on synthesis of phenoxy substituted double-decker phthalocyanine complexes of erbium(III) and gadolinium(III) and study of spectral properties.

\section{Experimental}

Electronic absorption spectra were registered using organic solvents (DMF and chloroform) by means of HITACHI U-2001 spectrophotometer under r.t. within $250-1000 \mathrm{~nm}$ wavelength range. IR spectra were obtained by means of «Avatar 360 FT-IR ESP» device in $400-4000 \mathrm{~cm}^{-1}$ range using $\mathrm{KBr}$ tablets. «Bruker DRX-500» (inner standard - TMS) device and $5 \%$ solution of phthalonitrile 1 were used in order to gain ${ }^{1} \mathrm{H}$ NMR spectrum.

Elemental analysis of synthesized compounds was performed by means of elemental analyzer CHNS-O FlashEA, 1112 series.

MALDI-TOF mass-spectra were registered by means of Shimadzu Biotech Axima Confidence mass-spectrometer in positiveion mode. The 2-(4-hydroxybenzoazo)benzoic acid was used as matrix. The samples were obtained by dissolving a compound in chloroform (2-6) $\left(C=10^{-5}-10^{-4} \mathrm{~mol} / \mathrm{L}\right)$ and mixing it with matrix's solution in DMF $(30 \mathrm{mg} / \mathrm{mL})$ in $1: 1(\mathrm{v} / \mathrm{v})$ ratio.

The samples were thermally treated under $110^{\circ} \mathrm{C}$ for 2 hours before performing elemental analysis.

4-\{[(1,1'-Biphenyl)-4-yl]oxy\}phthalonitrile (2). The compound was synthesized according to known method. ${ }^{[17]}$ Yield $82.6 \%$ (regarding 4-nitrophthalonitrile). Found, \%: C 80.93, H 4.21, N 9.11. $\mathrm{C}_{20} \mathrm{H}_{12} \mathrm{~N}_{2} \mathrm{O}$. Calculated: C 81.07, H 4.08, N 9.45. IR (KBr) $v_{\max } \mathrm{cm}^{-1}$ : $2230(\mathrm{C} \equiv \mathrm{N}), 1247(\mathrm{C}-\mathrm{O}-\mathrm{C}) .{ }^{1} \mathrm{H}$ NMR $\left(\mathrm{CDCl}_{3}\right) \delta_{\mathrm{H}} \mathrm{ppm}: 7.78-7.76 \mathrm{~d}$ $\left(\mathrm{H} 3,1 \mathrm{H}, J_{\text {нн }}=9.15 \mathrm{~Hz}\right), 7.70 \mathrm{~d}\left(\mathrm{H} 5,5,2 \mathrm{H}, J_{\text {нн }}=8.54 \mathrm{~Hz}\right), 7.62-7.61$ m (H1, 1H), 7.52-7.49 m (H6,6',2, 3H), 7.36 m (H8, 1H), 7.33-7.31 $\mathrm{m}\left(\mathrm{H} 7,7^{\prime}, 8,3 \mathrm{H}\right), 7.17-7.18 \mathrm{~d}\left(\mathrm{H} 4,4^{\prime}, 2 \mathrm{H}, J_{\mathrm{Hн}}=8.55 \mathrm{~Hz}\right)$.

4-[(4-Benzyloxy)phenoxy]phthalonitrile (3). ${ }^{[16]}$ 4-Nitrophthalonitrile of $1.73 \mathrm{~g}(0.01 \mathrm{~mol}), 2 \mathrm{~g}(0.01 \mathrm{~mol})$ of 4-benzyloxyphenol and $30 \mathrm{~mL}$ of DMF are loaded into flask equipped with mixer, reflux and thermometer. Solution of $2.07 \mathrm{~g}(0.015 \mathrm{~mol}) \mathrm{K}_{2} \mathrm{CO}_{3}$ is added to reaction mixture under intensive stirring after complete dissolving the reagents. The mixture is stirred under $50-60{ }^{\circ} \mathrm{C}$ for $15 \mathrm{~h}$. Resulting mixture is poured into $300 \mathrm{~mL}$ of water. Formed precipitate is filtered off, washed with water and dried under $70{ }^{\circ} \mathrm{C}$. Yield $2.80 \mathrm{~g}, 85.9 \%$ (regarding 4-nitrophthalonitrile). Found, \%: C 77.03, H 4.48, N 8.51. $\mathrm{C}_{21} \mathrm{H}_{14} \mathrm{~N}_{2} \mathrm{O}_{2}$. Calculated, \%: C 77.29, H 4.32, $\mathrm{N}$ 8.58. $\mathrm{m} / z$ MS (MALDI-TOF) $365[\mathrm{M}+\mathrm{K}-\mathrm{H}]^{+}$. IR (KBr) $v_{\max } \mathrm{cm}^{-1}$ : $2938\left(\mathrm{CH}_{2}\right), 2228(\mathrm{C} \equiv \mathrm{N}), 1237(\mathrm{C}-\mathrm{O}-\mathrm{C})$.

General method of synthesis of 2,9,16,23-tetra-4-\{[(1,1'biphenyl)-4-yl]oxy\}- (4) and 2,9,16,23-tetra-4-[4-(4-benzyloxy) phenoxy]phthalocyanines (5). Substituted phthalonitrile (2-3) of $1.0 \mathrm{mmol}$ and DBU of $0.15 \mathrm{~g}(1.0 \mathrm{mmol})$ are mixed in $10 \mathrm{~mL}$ of anhydrous isoamyl alcohol followed with refluxing for $6 \mathrm{~h}$. Reaction mixture is cooled and held for night. The precipitate is filtered off and washed with isoamyl alcohol, then dried. After that, the compound is washed with concentrated hydrochloric acid and water till neutral $\mathrm{pH}$, then dried. Final purification is performed by column chromatography using M 60 silica gel and chloroform as eluent.

2,9,16,23-Tetra-4-\{[(1,1'-biphenyl)-4-yl]oxy\}phthalocyanine (4). Yield $0.26 \mathrm{~g}, 87.7 \%$ (regarding compound 2). Found, \%: C 80.81, H 4.81, N 9.24. $\mathrm{C}_{80} \mathrm{H}_{50} \mathrm{~N}_{8} \mathrm{O}_{4}$. Calculated: $\mathrm{C} 80.93, \mathrm{H} 4.24, \mathrm{~N}$ 9.44. $\mathrm{m} / \mathrm{z}$ MS (MALDI-TOF) $1186.52[\mathrm{M}-\mathrm{H}]^{+}$. IR (KBr) $v_{\text {max }} \mathrm{cm}^{-1}$ : 1230 (C-O-C), 1006 ( $\left.\mathrm{H}_{2} \mathrm{Pc}\right)$.

2,9,16,23-Tetra-4-[4-(4-benzyloxy)phenoxy]phthalocyanine (5). Yield $0.28 \mathrm{~g}, 85.7 \%$ (regarding compound 3). Found, \%: C 77.08, $\mathrm{H}$ 4.61, N 8.35. $\mathrm{C}_{84} \mathrm{H}_{58} \mathrm{~N}_{8} \mathrm{O}_{8}$. Calculated, \%: C 77.17, H 4.47, $\mathrm{N}$ 8.57. $\mathrm{m} / \mathrm{z}$ MS (MALDI-TOF) $1308.13[\mathrm{M}+\mathrm{H}]^{+}$. IR (KBr) $v_{\mathrm{m}}$ $\mathrm{cm}^{-1}: 2919\left(\mathrm{CH}_{2}\right), 1216$ (C-O-C), $1011\left(\mathrm{H}_{2} \mathrm{Pc}\right)$.

General method of synthesis of erbium(III) and gadolinium(III) bis(2,9,16,23-tetra-4-\{[(1,1'-biphenyl)-4-yl] oxy\}phthalocyaninate) (6) and bis(2,9,16,23-tetra-4-[4-(4-benzyloxy)phenoxy] phthalocyaninate) (7). Mixture of $0.22 \mathrm{mmol}$ of phthalocyanine (4-5), $0.11 \mathrm{mmol}$ of anhydrous erbium(III) or gadolinium(III) chloride in $10 \mathrm{~mL}$ of $o$-dichlorobenzene is refluxed for $6 \mathrm{~h}$, cooled down, then $20 \mathrm{~mL}$ of chloroform is added, the solvent is removed. The rest is washed with ethanol, desired product is extracted with chloroform. Final purification is performed by column chromatography using M 60 silica gel and chloroform as eluent.

Bis(2,9,16,23-tetra-4-\{[(1,1'-biphenyl)-4-yl]oxy\}phthalocyaninate) of erbium(III) (6a). Yield $0.25 \mathrm{~g}, 44.8 \%$ (regarding compound 4). Found, \%: C 75.60, H 3.96, N 8.42. $\mathrm{C}_{160} \mathrm{H}_{96} \mathrm{ErN}_{16} \mathrm{O}_{8}$. Calculated: $\mathrm{C}$ 75.72, $\mathrm{H}$ 3.81, $\mathrm{N}$ 8.83. $\mathrm{m} / \mathrm{z}$ MS (MALDI-TOF) $2538.23[\mathrm{M}+\mathrm{H}]^{+}$. IR $(\mathrm{KBr}) v_{\max } \mathrm{cm}^{-1}: 1227(\mathrm{C}-\mathrm{O}-\mathrm{C})$.

Bis (2,9,16,23-tetra-4-\{[(1,1'-biphenyl)-4-yl]oxy\}phthalocyaninate) of gadolinium(III) (6b). Yield $0.31 \mathrm{~g}, 55.7 \%$ (regarding 4). Found, \%: C 75.92, H 3.90, N 8.72. $\mathrm{C}_{160} \mathrm{H}_{96} \mathrm{GdN}_{16} \mathrm{O}_{8}$. Calculated: C 76.02, H 3.83, N 8.87. $\mathrm{m} / \mathrm{z}$ MS (MALDI-TOF) 2527.57 [M] $]^{+}$. IR $(\mathrm{KBr}) v_{\max } \mathrm{cm}^{-1}: 1227$ (C-O-C).

Bis (2,9, 16,23-tetra-4-[4-(4-benzyloxy)phenoxy]phthalocyaninate) of erbium(III) (7a). Yield $0.29 \mathrm{~g}, 47.5 \%$ (regarding 5). Found, \%: C 72.51, $\mathrm{H} 4.12, \mathrm{~N}$ 7.92. $\mathrm{C}_{168} \mathrm{H}_{112} \operatorname{ErN}_{16} \mathrm{O}_{16}$. Calculated, \%: C 72.63, H 4.06, N 8.07. m/z MS (MALDI-TOF) 2778.69 [M] $]^{+}$. IR $v_{\max } \mathrm{cm}^{-1}: 2924\left(\mathrm{CH}_{2}\right), 1227(\mathrm{C}-\mathrm{O}-\mathrm{C})$.

Bis(2,9,16,23-tetra-4-[4-(4-benzyloxy)phenoxy]phthalocyaninate) of gadolinium(III) (7b). Yield $0.33 \mathrm{~g}, 54.2 \%$ (regarding 5). Found, \%: C 72.79, H 4.13, N 8.00. $\mathrm{C}_{168} \mathrm{H}_{112} \mathrm{GdN}_{16} \mathrm{O}_{16}$. Calculated, \%: C 72.90, H 4.08, N 8.10. $\mathrm{m} / z$ MS (MALDI-TOF) 2769.42 $[\mathrm{M}+\mathrm{H}]^{+}$. IR $v_{\max } \mathrm{cm}^{-1}: 2922\left(\mathrm{CH}_{2}\right), 1227(\mathrm{C}-\mathrm{O}-\mathrm{C})$.

\section{Results and Discussion}

\section{Synthesis}

Initial compounds used for synthesis of double-decker phthalocyaninates were phenoxy-substituted phthalonitriles 
2-3, which were obtained by nucleophilic substitution of nitro-group being part of 4-nitrophthalonitrile (1) on 4-phenylphenol ${ }^{[17]}$ or 4-benzyloxyphenyl ${ }^{[16]}$ groups (Scheme 1). Reaction was carried out in DMF in presence of potash under temperature of $50-60{ }^{\circ} \mathrm{C}$ for 15 hours. The precipitate formed after finishing reaction was washed with water and dried by air under $70^{\circ} \mathrm{C}$.

Obtaining homoleptic double-decker complexes of lanthanides is known to be performed by template condensation as well as metalation of free ligand.$^{[1-3,8]}$ The work ${ }^{[18]}$ reports the method of obtaining diphthalocyanines by refluxing phthalonitrile annulated by crown ether fragment (15C5) with lanthanide salt within isoamyl alcohol in presence of DBU. The same procedure using phthalonitriles 2-3 under the same conditions resulted in wrong products. Phthalocyanine ligand was mainly formed upon synthesis with erbium chloride and complexes of planar and sandwich structure were observed in mixture upon using gadolinium and nitrile 3. Separation of the products was performed by chromatography on silica-gel M60. Chloroform being eluent was shown to extract gadolinium diphthalocyanine and chloroform-ethanol mixture $(8: 1)$ extracted monocomplex. The difference between obtained results and known data $^{[18]}$ is mainly caused by nature of phthalonitriles and metal salts. In this way, using salt of gadolinium of ionic radius close to terbium ${ }^{[18]}$ gives formation of desired metal complexes, whereas salt of erbium having smaller ionic radius provides formation of phthalocyanine ligand only. Changing metals from $\mathrm{Er}$ and $\mathrm{Lu}$ to $\mathrm{Eu}$ and $\mathrm{Gd}$ was described previously $^{[2,3]}$ to increase yields of diphthalocyanines obtained by template condensation method.

Metaling the free ligand with lanthanide salts in refluxing solvent is known to be the way of double-decker phthalocyaninates' obtainment. ${ }^{[2,3]}$ In accordance with that the next step of work was synthesis of metal-free phenoxy-substituted phthalocyanines (4-5).

Substituted phthalonitrile (2-3) was refluxed in isoamyl alcohol in presence of strong base being DBU for 6 hours till free ligand's formation (4-5) (Scheme 2). Extraction of the product was performed by filtration, flushing with isoamyl alcohol and water till neutral $\mathrm{pH}$. Final purification was performed by column chromatography. Tetrasubstituted phthalocyanines are formed as mixture of four inseparable isomers having $\mathrm{D}_{2 \mathrm{~h}}, \mathrm{C}_{4 \mathrm{~h}}, \mathrm{C}_{2 \mathrm{v}}$ and $\mathrm{C}_{\mathrm{s}}$ - symmetry. ${ }^{[16,19,20]}$

Next, obtained free ligand was metallized by anhydrous erbium(III) or gadolinium(III) chlorides in refluxing $o$-chlorobenzene. The process was carried out both with DBU and without in order to select optimum conditions. Reaction control was performed by means of electron absorption spectroscopy (UV-Vis). UV-Vis spectrum
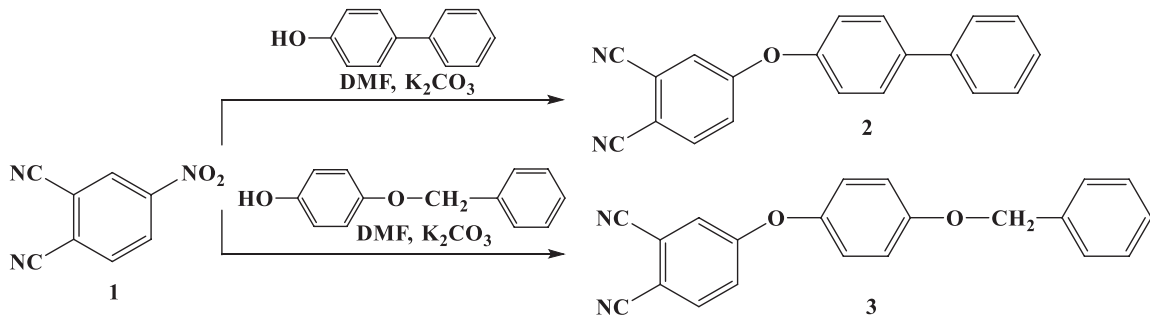

Scheme 1.
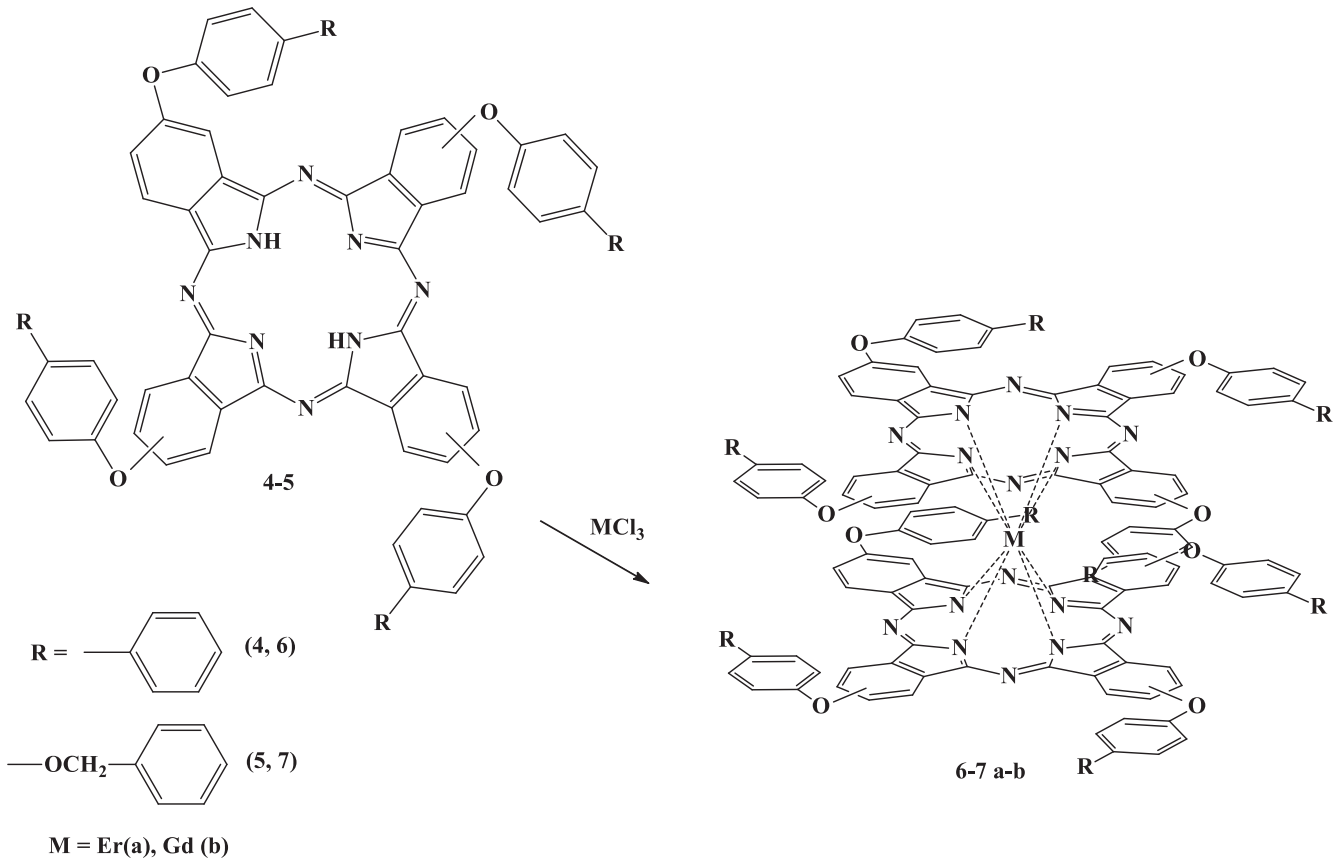

Scheme 2. 
of mixture containing DBU in chloroform demonstrates big number of bands indicating formation of complexes different in structure. And spectrum of the mixture without the base in the same solvent contains bands typical for double-decker complex. Suchlike regularities were noticed previously as characteristics of double-decker phthalocyaninates peripherally substituted with alkyl terminal fragments. ${ }^{[2]}$ In this way, synthesis of desired doubledecker phthalocyaninates was performed by metalation of free ligand with erbium(III) or gadolinium(III) chlorides in refluxing $o$-dichlorobenzene (Scheme 2). Resulting mixture of mono- and double-decker complexes was separated by multi-step chromatography.

Structure of all synthesized compounds was proved by IR, UV-Vis spectroscopy and mass-spectrometry.

Mass-spectrometric studies of obtained complexes were performed using MALDI-TOF method. Mass spectra of all double-decker phthalocyaninates and free ligands contain lines of molecular ions $[\mathrm{M}]^{+}$for $\mathbf{6 b}, 7 \mathbf{a}$ and $[\mathrm{M}+\mathrm{H}]^{+}$ for $4,5,6 a, 7 b$.

IR spectra of 2-3 demonstrate bands (2228-2230 $\left.\mathrm{cm}^{-1}\right)$ responding to valent vibrations of cyano-group. The spectra of all synthesized compounds 2-7 register characteristic absorption of C-O-C band $\left(1216-1247 \mathrm{~cm}^{-1}\right) .{ }^{[21]}$ The spectra of compounds containing benzylphenoxy-group $(\mathbf{3}, \mathbf{5}, \mathbf{7})$ have a band (2919-2938 $\mathrm{cm}^{-1}$ ) assigned to valent vibrations of methylene $\mathrm{C}-\mathrm{H}$ bond. ${ }^{[22]}$ There is absorption band (1006-1011 $\left.\mathrm{cm}^{-1}\right)$ corresponding to metal-free phthalocyanine observed for 2,9,16,23-tetra-4-\{[(1,1'-biphenyl)-4-yl $]$ oxy - (4) and 2,9,16,23-tetra-4-[4-(4-benzyloxy)phenoxy] phthalocyanines (5). ${ }^{[23]}$

UV-Vis spectral data for the synthesized phthalocyanines are presented in Table 1.

Spectral curves of free ligands (4-5) in chloroform and DMF demonstrate a duplet in long-wavelength region (Table 1) being characteristic for metal-free compounds and caused by $\mathrm{D}_{4 \mathrm{~h}}$ symmetry of the molecule. ${ }^{[23,24]}$

One Q-band in UV-Vis spectrum appears upon transfer from metal-free phthalocyaines (4-5) to corresponding metal complexes (6-7) in chloroform (Figure 1, Table 1). Additionally, wide band of low intensity appears in range of 450-500 nm (Figures 1, 2, Table 1) being characteristic for neutral-radical "green" forms of double-decker lanthanide complexes. ${ }^{[25]}$

Table 1. Data of UV-Vis spectra of compounds 4-7.

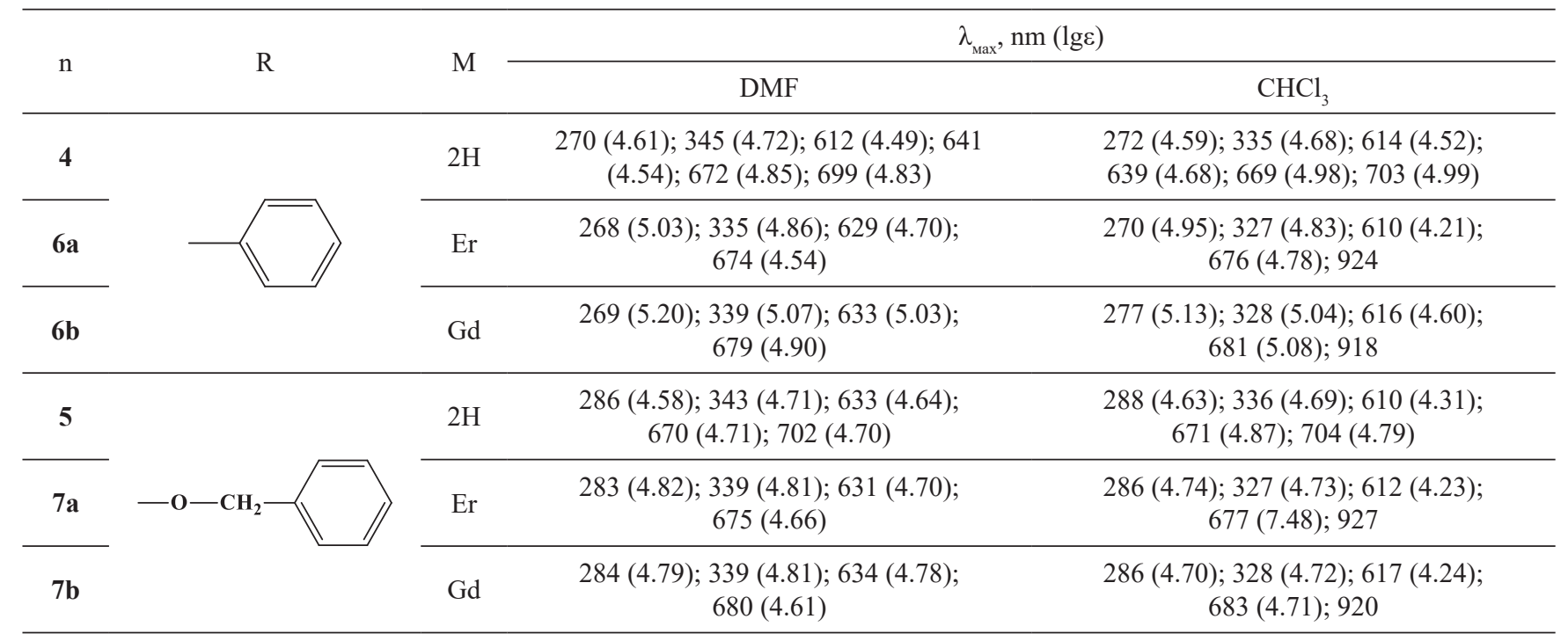

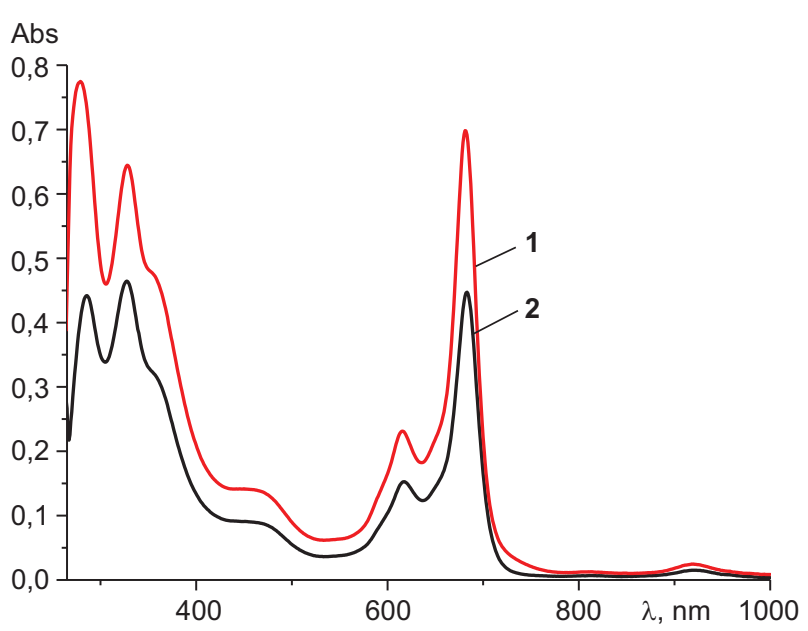

Figure 1. UV-Vis spectra in $\mathrm{CHCl}_{3}: 1-\mathbf{6 b}\left(5.86 \cdot 10^{-6} \mathrm{M}\right)$; $2-7 \mathbf{b}\left(8.81 \cdot 10^{-6} \mathrm{M}\right)$.

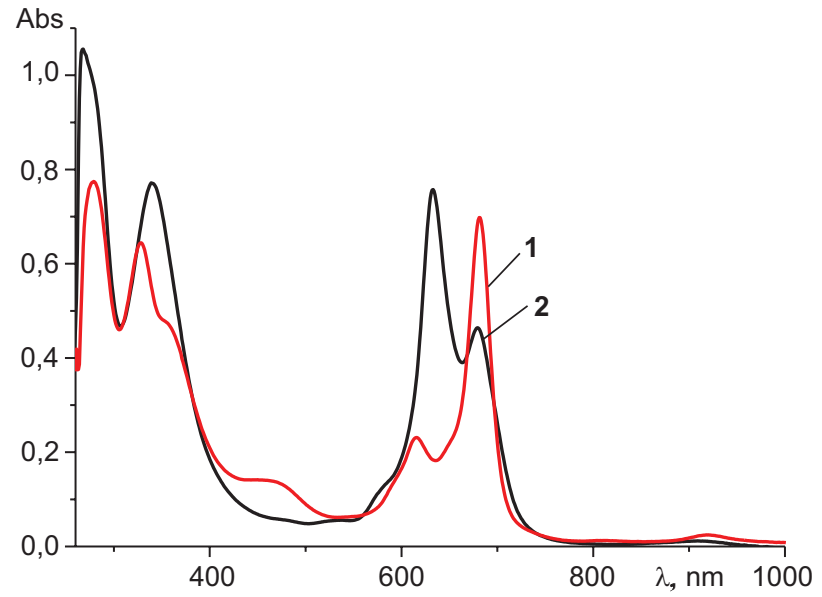

Figure 2. UV-Vis spectra of $\mathbf{6 b}$ : 1 - in $\mathrm{CHCl}_{3}\left(5.86 \cdot 10^{-6} \mathrm{M}\right)$; 2 - in DMF $\left(6.51 \cdot 10^{-6} \mathrm{M}\right)$. 
Replacing chloroform with DMF changes UV-Vis spectrum of complexes 6-7 (Figure 2). The part located in long-wavelength regions is transformed into double-band spectrum having maxima at 674-680 and 630-633 nm, herewith short-wavelength component becomes more intensive and wide band at 450-500 $\mathrm{nm}$ disappears that corresponds to transformation of complex $\mathbf{5}$ into anionic "blue" form.

The character of spectrum is noticed to depend on complexation metal. Erbium complexes (6a, 7a) demonstrate incomplete degradation observed upon analysing absorption bands' positions and its ratio in DMF exhibiting initial Q-band (Figure 3, curve 2). Band at $674 \mathrm{~nm}$ disappears and absorption band at $698 \mathrm{~nm}$ appears upon addition of $1 \%$ hydrazine hydrate in DMF solution of complex $6 \mathbf{6}$ (Figure 3, curve 1). This indicates complete transformation of the complex into anionic form. Similar spectral behaviour was shown to occur for THF solution of complex 6a upon addition of $1 \%$ hydrazine hydrate (Figure 3, curve 3 ). Moreover, spectral curves were observed to correspond to reduced "blue" form after long-time storing within DMF (Figure 3, curve 4).

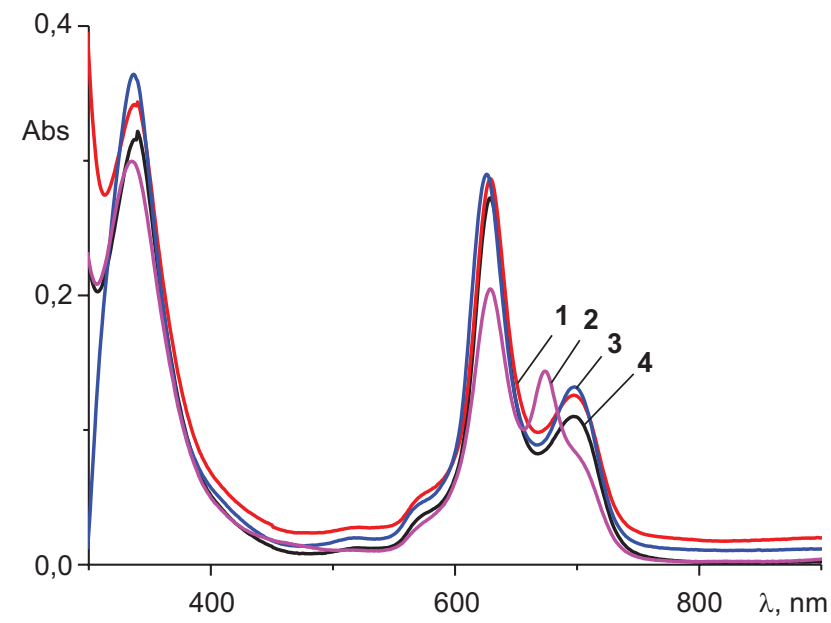

Figure 3. UV-Vis spectra of 6a: 1 - in DMF $+1 \% \mathrm{NH}_{2} \mathrm{NH}_{2} \cdot \mathrm{H}_{2} \mathrm{O}$; 2 - in DMF (freshly obtained); 3 - in THF $+1 \% \mathrm{NH}_{2} \mathrm{NH}_{2} \cdot \mathrm{H}_{2} \mathrm{O}$; $4-$ in DMF (9 days of storing).

Replacing complexation metal erbium with gadolinium changes the spectra. UV-Vis spectrum in freshly obtained DMF solution of $\mathbf{6} \mathbf{b}$ complex is characterized by two absorption maxima (Figure 4, curve 2). Addition of $1 \%$ hydrazine hydrate as reducing agent into the solution slightly increase the intensity of short-wave band and decrease long-wave one exhibiting bathochromic shift for $8 \mathrm{~nm}$. The form and position of absorption bands for $\mathbf{6 b}$ in both DMF with $1 \%$ hydrazine hydrate and THF with $1 \%$ hydrazine hydrate as well as in DMF upon long-time storing were shown to be almost similar (Figure 4). There was no initial Q-band observed in UV-Vis spectrum of freshly obtained DMF solution of $\mathbf{6 b}$ that most probably indicated the reduction process of gadolinium complex 6b into anionic "blue" form to proceed rather faster and easier than in case of erbium complex $\mathbf{6 a}$ under the same conditions.

In sum, one can notice the diphthaloyanines containing bulky aryloxy substituents $(6,7)$ to be significantly

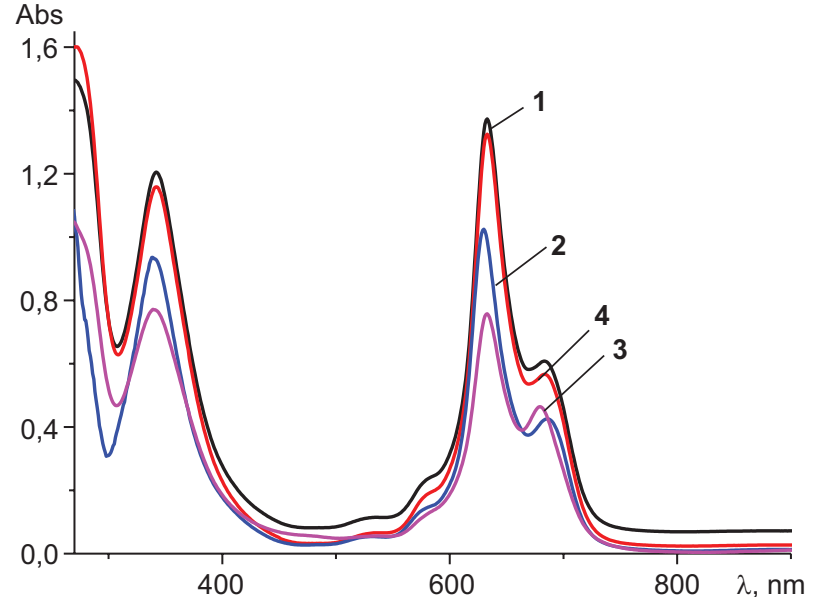

Figure 4. UV-Vis spectra of $6 \mathbf{b}: 1-$ in DMF $+1 \% \mathrm{NH}_{2} \mathrm{NH}_{2} \cdot \mathrm{H}_{2} \mathrm{O}$; 2 - in DMF (freshly obtained); 3 - in THF $+1 \% \mathrm{NH}_{2} \mathrm{NH}_{2} \cdot \mathrm{H}_{2} \mathrm{O}$; 4 - in DMF (9 days storing).

affected by nature of a lanthanide regarding reduction of neutrally-radical "green" forms to anionic "blue" ones in DMF medium. Increasing ionic radius of a metal makes reduction easier.

Replacing erbium being metal template $(\mathbf{6 a}, 7 \mathbf{7})$ with gadolinium $(\mathbf{6 b}, \mathbf{7 b})$ is accompanied with bathochromic shift of all bands in organic solvents (Table 1). Nature of phenoxygroups of the substituent has almost no influence on position of UV-Vis bands.

\section{Conclusions}

The synthesis of phenoxy-substituted phthalonitriles and free phthalocyanine ligands based on them was carried out. Corresponding double-decker complexes with erbium(III) and gadolinium(III) were obtained by the metalation of free ligands. Spectral characteristics of all synthesized compounds were studied. Replacing erbium being metal template with gadolinium was found to shift all absorption bands into red region in organic solvent medium. Influence of lanthanide's nature on reduction of neutrally-radical "green" forms to anionic "blue" ones in DMF medium for the synthesized diphthalocyanines was established.

Acknowledgements. The work was supported by Russian Science Foundation (project 17-73-20017).

\section{References}

1. Smola S.S., Snurnikova O.V., Fadeyev E.N., Sinelshchikova A.A., Gorbunova Y.G., Lapkina L.A., Tsivadze A.Yu., Rusakova N.V. Macroheterocycles 2012, 5, 343-349.

2. Tolbin A.Yu., Breusova M.O., Tomilova L.G., Pushkarev V.E. Russ. Chem. Bull. 2005, 54, 2083-2086.

3. Pushkarev V.E., Tomilova L.G., Tomilov Y.V. Russ. Chem. Rev. 2008, 77, 875-907.

4. Belogorokhov I.A., Pashkova N.V., Kladova E.I., Tikhonov E.V., Belogorokhova L.I., Tomilova L.G., Khokhlov D.R., 
Dronov M.A., Ryabchikov Y.V. Semiconductors 2011, 45, 1453-1456.

5. Belogorokhov I.A., Ryabchikov Yu.V., Tikhonov E.V., Pushkarev V.E., Breusova M.O., Tomilova L.G., Khokhlov D.R. Semiconductors 2008, 42, 321-324.

6. Bunzli J.C.G., Comby S., Chauvin A.S., Vandevyver C.D.B. J. Rare Earths. 2007, 25, 257-274.

7. Bo Sh., Hu J., Wang Q., Liua X., Zhen Z. Photochem. Photobiol. Sci. 2008, 7, 474-479.

8. Oluwole D.O., Yagodin A.V., Mkhize N.C., Sekhosana K.E., Martynov A.G., Gorbunova Yu.G., Tsivadze A.Yu., Nyokong T. Chem. Eur. J. 2017, 23, 2820-2830.

9. Gerasymchuk Y., Tomachynski L., Tretyakova I., Hanuza J., Legendziewicz J. J. Photochem. Photobiol., A: Chem. 2010, $214,128-134$.

10. Gerasymchuk Yu., Tomachynski L., Guzik M., Koll A., Janski J., Guyot Y., Strek W., Boulon G. Legendziewicz J. J. Photochem. Photobiol., A: Chem. 2015, 309, 65-71.

11. Dubinina T., Paramonova K., Trashin S., Borisova N.E., Tomilova L.G., Zefirov N.S. Dalton Trans. 2014, 43, 27992809.

12. Martynov A.G., Safonova E.A., Gorbunova Yu.G., Tsivadze A. Yu. Russ. J. Inorg. Chem. 2010, 55, 347-354.

13. Lobanov A.V., Gromova G.A., Gorbunova Y.G., Tsivadze A.Y. Protect. Met. Phys. Chem. Surf. 2014, 50, 570-577.

14. Gorbunova Y.G., Martynov A., Stuzhin P., Koifman O.I. Macroheterocycles 2017, 10, 400-409.

15. Takagi Y., Ohta K., Shimosugi Sh., Fujiia T., Itoh E. J. Mater. Chem. 2012, 22, 14418-14425.
16. Durmus M., Nyokong T. Polyhedron 2007, 26, 2767-2776.

17. US Patent 20080004391. Chan K., Genovese S., Hagberg E., Hall D., Maxam J., Mullen T., Odle R., Stella A., White J. Methods of preparing polymer-organoclay composites and articles derived therefrom. Resiv. 21.06.2007. Publ. 03.01. 2008.

18. Birin K.P., Gorbunova Y.G., Tsivadze A.Yu. Dalton Trans. 2012, 41, 9672-9681.

19. Kadish K.M., Smith K.M., Guilard R. In: The Porphyrin Handbook, Vol 15. Academic Press: Elsevier Science, 2003, $3925 \mathrm{p}$.

20. Jiang Z., Ou Z., Chen N., Wang J., Huang J., Shao J., Kadish K.M. J. Porphyrins Phthalocyanines 2005, 9, 352-360.

21. Dayer J.R. Applications of Absorption Spectroscopy of Organic Compounds. Prentice-Hall. Inc. NY.: Enclewood Cliffs, 1970. $163 \mathrm{p}$.

22. Pretsch E., Bullmann F., Affolter C. Structural Determination of Organic Compounds. Tables of Spectral Data. Springer, 2006. $438 \mathrm{p}$.

23. Znoiko S.A., Akopova O.B., Bumbina N.V., Usoltseva N.V., Maizlish V.E., Shaposhnikov G.P., Abramov I.G. Russ. J. Gen. Chem. 2014, 84, 708-714.

24. Berezin B.D., Berezin D.B. Chromophoric System of Macrocycles and Linear Molecules. Moscow: Krasand, 2013. 240 p. (in Russ.) [Березин Б.Д., Березин Д.Б. Хромофорные системы макрочиклов и линейных молекул. М: Красанд, 2013. 240 c.].

25. Basova T., Jushina I., Gürek A.G., Ahsen V., Ray A.K. J. R. Soc. Interface 2008, 5, 801-806. 